\title{
Problem-based learning approach to improve service skills of badminton in physical education learning
}

\author{
Rusfan Dinata Prabandaru ${ }^{\mathrm{a}, 1, *}$, Lismadiana Lismadiana ${ }^{\mathrm{a}, 2}$, Fitri Agung Nanda ${ }^{\mathrm{a}, 3}$ \\ ${ }^{a}$ Departement of Sport Science, Graduate School Universitas Negeri Yogyakarta, Indonesia \\ ${ }^{1}$ rusfandinata12@gmail.com; ${ }^{2}$ lismadiana@gmail.com; ${ }^{3}$ fitriagungnanda16@ gmail.com \\ * corresponding author
}

ARTICLE INFO

Article history

Received 2020-01-06

Revised 2020-02-22

Accepted 2020-03-10

Keywords

Badminton

Problem based learning

Service hitting skill

\section{ABSTRACT}

Problem-based learning is a method used to solve a problem in learning. This study aimed to determine whether learning badminton service skills by applying a problem-based learning approach can improve badminton service hit skills. The research method uses the classroom action research (CAR) method by interpreting the data and comparing each cycle's results with a percentage approach to measure the achievements of the actions taken. The results obtained from the data taken before the action were $23.68 \%$ of students who mastered basic movement skills hitting badminton service. After the first cycle, $34.21 \%$ of the students mastered the material, and, at the end of the second cycle, $52.63 \%$ of the students mastered the basic movement skills of hitting badminton service. From the preliminary data, there was a significant increase in cycle I and cycle II, the conclusion is that there increased the skill of hitting badminton service through the problem based learning approach (PBL) in students of third-grade of Pagergunung elementary school 1 in 2018/2019. Increased mastery of hitting service skills badminton, which was improved through applying the problem-based approach, was $28.94 \%$.

This is an open-access article under the CC-BY-SA license.

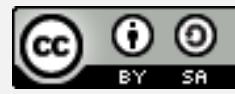

\section{Introduction}

Badminton is a popular sport among the people of Indonesia, and badminton also one of the material taught in physical education in Indonesia [1]. In learning, Students will lead to doing service due to is the beginning of badminton service is a hit to start the game that aims to get the point [2]. Service hit is a very decisive hit for the score. Because, players who do good service may say as able to control the game, and service is assumed as one of the initial strategies in badminton [3], [4]. That service hit is one of the shots taken to start a match, and a shot was done by flying a shuttlecock into the opponent's playing field in a diagonal direction.

Discussing the learning of service that is taught in Physical Education learning. The author notes that there is one problem that occurs in the field of services performed. Problems regarding services that do not achieve learning targets occur in Pagergunung State Primary School I grade 3 (three). Problems that arise are many students who are difficult in making service punches using a racket and how come, this is by accordance with the results of the evaluation of badminton playing skills that show that many students lack mastery of competence as indicated by the small number of students who get results above KKM (Minimum completeness criteria). Students find it difficult to carry out attitudes and steps in doing service well. Badminton service is a very important thing to play because it is the beginning of a game or a match. Based on the observations, it needs the method for delivering material about service in badminton to increase the academic score of students to pass the KKM. Problem-based solving is one method recommended for learning. 
The problem-based learning method is a method used to solve a problem in learning. [5]-[7], problem-based learning (PBL) is a series of learning activities that emphasize the problem-solving process scientifically. The nature of the problem raised in Problem Based Learning is the gap between the real situation and the expected situation, or between real and expectations. The gap that occurs in badminton learning is, the inability of students to perform services that result in the value of students found to be less than the KKM that should be met to solve this problem a new method is applied in learning, discussion of learning methods that are considered good for solving this problem is the problem of based learning. Problem Based Learning is the method prepares students to think critically and analytically and to find and use appropriate learning resources [8]. According to Trianto Problem Based Learning is a learning model based on the problems that require authentic inquiry, that is, investigations require real resolution of real problems. From these opinions, Problem Based Learning puts the concept of understanding. The application of learning models using problem-based learning was able to improve student learning outcomes. Moreover, problem-based learning can give a big influence on increasing the results above the KKM score.

Meanwhile, argue that Problem Based Learning has a solution that must be solved by the person concerned [9]. The teachers should use the Problem Based Learning (PBL) model consistently because it has proven its success to solve problems and cognitive learning outcomes [10]. Showed that problem-based learning was carried out as expected and could improve problem-solving abilities in Sananwetan Elementary School 2 in Blitar, East Java. By the problems found, the article tried to apply the problem-based learning model to determine whether there are differences in the results of badminton service hitting in third-grade students at Pagergunung Elementary School Problem-based learning model approach is deemed appropriate to solve the problem because it is a learning model based on a person who has a problem must find or think about a way out in solving the problem [11]. In the end, the person has the important role of problem-solving experienced.

\section{Method}

The particular research used the Classroom Action Research design. The subjects were students of third Grade at Pagergunung Elementary School, Temanggung Regency in Academic Year of 2018/2019 with a total of 38 students. The subjects were based on the physical education subjects of KD (Basic Competence) Badminton Service. Data collection techniques were test and non-test. The test aimed to reveal the success of student learning outcomes by applying methods for work in the assessment of learning material of small ball game of basic motion on Services hitting in playing badminton on third-grade 3 students of Pagergunung Elementary School. And, non-test was done by observation. Observation is used to answer the problems raised in the study.

The research intended in this study uses two cycles in the application of the problem-based learning model, Fig 1. explain the two cycles to be carried out in this study can be seen in the framework.
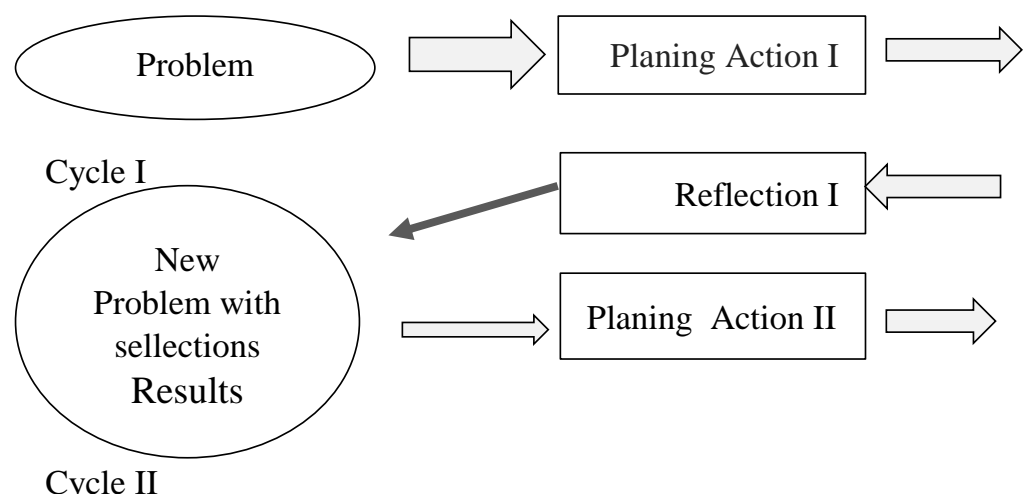

Implementation Action I

Cycle II

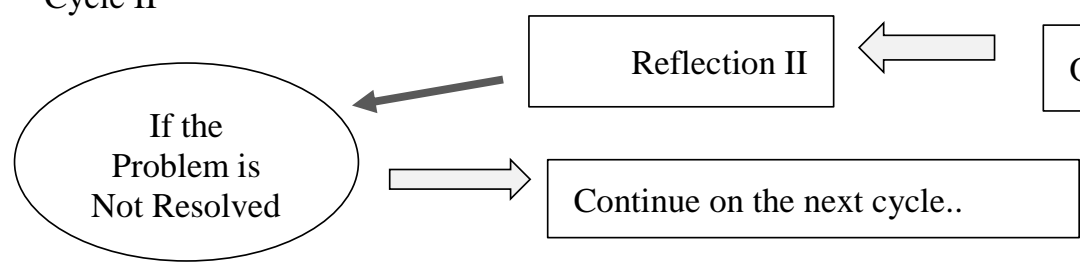

Fig. 1. Framework research PTK cycle I and cycle II. 


\section{Results and Discussion}

Cycle I explain that activity was carried out in line with the previous researchers' design, which was to make a direct application design using a problem-based learning approach in game to improve badminton service hitting skills. However, before the researcher began the research, the researcher had already carried out a classroom action simulation. Cycle I was held in 2 meetings. Cycles 1 and 2 can be seen in Fig 1. The obtained results at the observation stage were collected and analyzed from these results.

After conducting the research, the results showed that students were able to master service punches in badminton. Of the 38 students, there were only 13 students who were able to do badminton service well. If included in the percentage of learning outcomes there are only $34.21 \%$ of students who can graduate and reach the KKM target of learning badminton service. Based on the results of the data obtained, there are still many who have not reached the desired research target, therefore the results of this study are used as references for the second cycle. Data obtained by each student when doing service can be seen in Table 1.

Table 1. Results of Classroom Action On Cycle I

\begin{tabular}{|c|c|c|c|}
\hline NAME & Score & Percentage (\%) & Criteria \\
\hline Alfiansyah & 10 & $100 \%$ & mastered \\
\hline Andrea Revaldo Yofananta & 10 & $100 \%$ & mastered \\
\hline Angga Haekal Akbar & 6 & $60 \%$ & Not mastered \\
\hline Arfan Pratama Siregar & 5 & $50 \%$ & Not mastered \\
\hline Berta Ayundya & 10 & $100 \%$ & Mastered \\
\hline Denis Chaedar Pratama & 6 & $60 \%$ & Not mastered \\
\hline Dhea Kayla Nesya & 3 & $30 \%$ & Not mastered \\
\hline Djibril Krisna.$R$ & 5 & $50 \%$ & Not mastered \\
\hline Elifa Baryza Qonita & 6 & $60 \%$ & Not mastered \\
\hline Fadhil Erda Rahman & 7 & $70 \%$ & Not mastered \\
\hline Faith Edgar Syaif & 5 & $50 \%$ & Not mastered \\
\hline Fara Ayudyabbudi Astuti & 10 & $100 \%$ & mastered \\
\hline Fardhan Yunas Pahlevi & 10 & $100 \%$ & mastered \\
\hline Faza Afta Daniel & 4 & $40 \%$ & Not mastered \\
\hline Felice Hayati Widi .W & 6 & $60 \%$ & Not mastered \\
\hline Galang Raditya Arya .S & 10 & $100 \%$ & mastered \\
\hline Herda Kayla Natasya & 7 & $70 \%$ & Not mastered \\
\hline Ihza Aliya Hermawan & 7 & $70 \%$ & Not mastered \\
\hline Jauza Rayya Rabbani & 6 & $60 \%$ & Not mastered \\
\hline Jhian Candra Gupta & 3 & $30 \%$ & Not mastered \\
\hline Lentera Nauva & 10 & $100 \%$ & mastered \\
\hline Luthfi Khanifatu Satiroh & 7 & $70 \%$ & Not mastered \\
\hline Muhamad Aulia Rahman & 10 & $100 \%$ & mastered \\
\hline Muhamad Dwi Irawan & 5 & $50 \%$ & Not mastered \\
\hline Muhamad Fajar & 10 & $100 \%$ & mastered \\
\hline Muhamad Faris Rahman & 3 & $30 \%$ & Not mastered \\
\hline Muhamad Giska Ramadhan & 4 & $40 \%$ & Not mastered \\
\hline Muhamad Reval Dwi .S & 6 & $60 \%$ & Not mastered \\
\hline Muhamad Riyan Hadziq & 3 & $30 \%$ & Not mastered \\
\hline Muhammad Azril Ilham & 10 & $100 \%$ & mastered \\
\hline Nahla Ikhmalia Bariq .A & 6 & $60 \%$ & Not mastered \\
\hline Novi Tsatuzzahro & 10 & $100 \%$ & mastered \\
\hline Nur. M. Habib Prastyawan & 3 & $30 \%$ & Not mastered \\
\hline Rechan Aldi Saputra & 10 & $100 \%$ & mastered \\
\hline Renata Rizki Abidin & 3 & $30 \%$ & Not mastered \\
\hline Salwa Chavida Rahmadhani & 6 & $60 \%$ & Not mastered \\
\hline Yodha Karisma Zufar & 10 & $100 \%$ & mastered \\
\hline Zada Siraj & 6 & $60 \%$ & Not mastered \\
\hline Total of score & 258 & $67,89 \%$ & 13 \\
\hline Mean & 6.79 & $67,89 \%$ & $34.21 \%$ \\
\hline
\end{tabular}

Table 1. explained there 13 students mastered the badminton service hitting skills or $\mathbf{3 4 . 2 1 \%}$. After obtained the score after cycle 1, the next step is to compare the data with the performance indicators; increasing the ability of basic movement of service hitting of badminton. Marked by the increasing 
the score and percentage of basic movement of service hitting of Badminton. The indicators of success are the Minimum completeness Criteria (KKM) of 75.

Students obtained score more than 75 are completed or mastered, while students obtained score less than 75 are incomplete or not mastered. In sum, 13 students mastered the skills or $\mathbf{3 4 . 2 1 \%}$. The results of the presentation shown in the above table if entered into the diagram can be seen in the image below. The part that shows blue is the result of service punches from children who can do it well and vice versa with the parts shown by orange is the result of presentations from students who cannot do service punches properly in cycle I, and the diagram can be seen in Fig 2. below:

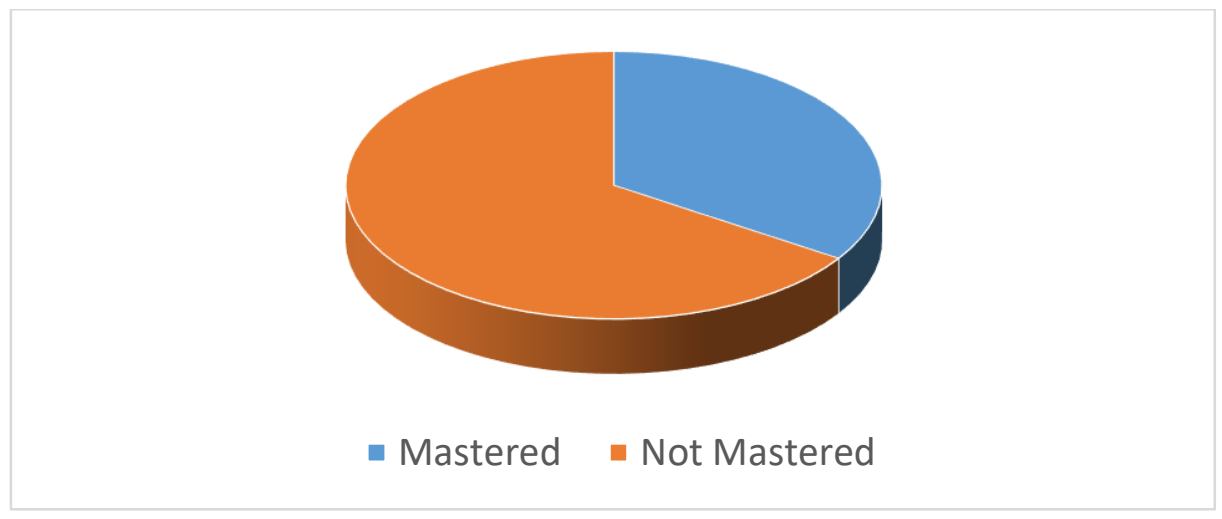

Fig. 2. Diagram of Badminton Service Hitting Mastery with Criteria After Cycle 1

The research data, then compared with the initial conditions obtained by students which increased from the beginning / pre-cycle were 9 students, increased to 13 students. And, the average badminton skills lost from $59.74 \%$, increasing to $67.89 \%$. The results of the interesting presentations in the table above is included in the diagram can be seen in the picture below. The part that shows blue is the result of children's punches that can be done well and vice versa with the part that is shown by the orange color is the result of the presence of students who can not do a good punch service in the cycle I compare with the pre-cycle, the presentation can be seen in Fig 3. below:

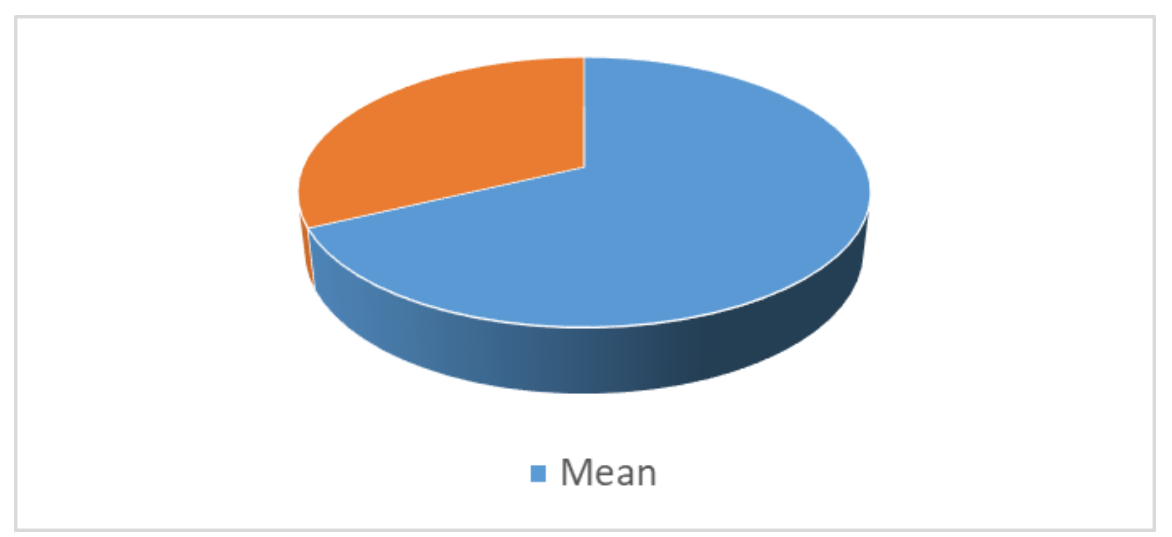

Fig. 3. Diagram of Badminton Service Hitting Mastery, Mean of the Class After Cycle 1

\section{Cycle II}

Because the results in cycle I did not reach the expectations, it continues to cycle II to strengthen the actions and improve the results of the study, as a reinforcement of the results obtained in cycle I. Implementation in cycle II is still using the same approach in the previous of cycle I, which is the direct application of using the problem-based learning approach in a game with aim to improve Service Hitting of Badminton. 
Below there is table 2 that explains the results obtained, in the observation of cycle II are collected and analyzed. Then, it continued to reflect by looking at observational data whether the activities in cycle II has been able to improve the mastery of service hitting of badminton. From the results of the test of badminton service skills, students mastered the service hitting of badminton in cycle II was 20 children or $\mathbf{5 2 . 6 3 \%}$. The data is presented in the following Table 2 .

Table 2. Results of CAR on Cycle II

\begin{tabular}{|c|c|c|c|}
\hline Name & Score & Percentage (\%) & Criteria \\
\hline Alfiansyah & 10 & $100 \%$ & Mastered \\
\hline Andrea Revaldo Yofananta & 10 & $100 \%$ & Mastered \\
\hline Angga Haekal Akbar & 6 & $60 \%$ & Not mastered \\
\hline Arfan Pratama Siregar & 7 & $70 \%$ & Not mastered \\
\hline Berta Ayundya & 10 & $100 \%$ & Mastered \\
\hline Denis Chaedar Pratama & 6 & $60 \%$ & Not mastered \\
\hline Dhea Kayla Nesya & 10 & $100 \%$ & Mastered \\
\hline Djibril Krisna .R & 7 & $70 \%$ & Not mastered \\
\hline Elifa Baryza Qonita & 10 & $100 \%$ & Mastered \\
\hline Fadhil Erda Rahman & 7 & $70 \%$ & Not mastered \\
\hline Faith Edgar Syaif & 5 & $50 \%$ & Not mastered \\
\hline Fara Ayudyabbudi Astuti & 10 & $100 \%$ & Mastered \\
\hline Fardhan Yunas Pahlevi & 10 & $100 \%$ & Mastered \\
\hline Faza Afta Daniel & 7 & $70 \%$ & Not mastered \\
\hline Felice Hayati Widi .W & 6 & $60 \%$ & Not mastered \\
\hline Galang Raditya Arya .S & 10 & $100 \%$ & Mastered \\
\hline Herda Kayla Natasya & 7 & $70 \%$ & Not mastered \\
\hline Ihza Aliya Hermawan & 10 & $100 \%$ & Mastered \\
\hline Jauza Rayya Rabbani & 10 & $100 \%$ & Mastered \\
\hline Jhian Candra Gupta & 3 & $30 \%$ & Not mastered \\
\hline Lentera Nauva & 10 & $100 \%$ & Mastered \\
\hline Luthfi Khanifatu Satiroh & 7 & $70 \%$ & Not mastered \\
\hline Muhamad Aulia Rahman & 10 & $100 \%$ & Mastered \\
\hline Muhamad Dwi Irawan & 5 & $50 \%$ & Not mastered \\
\hline Muhamad Fajar & 10 & $100 \%$ & Mastered \\
\hline Muhamad Faris Rahman & 7 & $70 \%$ & Not mastered \\
\hline Muhamad Giska Ramadhan & 4 & $40 \%$ & Not mastered \\
\hline Muhamad Reval Dwi .S & 10 & $100 \%$ & Mastered \\
\hline Muhamad Riyan Hadziq & 10 & $100 \%$ & Mastered \\
\hline Muhammad Azril Ilham & 10 & $100 \%$ & Mastered \\
\hline Nahla Ikhmalia Bariq .A & 6 & $60 \%$ & Not mastered \\
\hline Novi Tsatuzzahro & 10 & $100 \%$ & Mastered \\
\hline Nur. M. Habib Prastyawan & 7 & $70 \%$ & Not mastered \\
\hline Rechan Aldi Saputra & 10 & $100 \%$ & Mastered \\
\hline Renata Rizki Abidin & 7 & $70 \%$ & Not mastered \\
\hline Salwa Chavida Rahmadhani & 10 & $100 \%$ & Mastered \\
\hline Yodha Karisma Zufar & 10 & $100 \%$ & Mastered \\
\hline Zada Siraj & 7 & $70 \%$ & Not mastered \\
\hline Total of Score & 311 & $81.84 \%$ & 20 \\
\hline Mean & 8.18 & $81.84 \%$ & $52.63 \%$ \\
\hline
\end{tabular}

In Fig 4. is the results of the Service Hitting of Badminton, students mastered Badminton Service hitting after cycle II was 20 students or $\mathbf{5 2 . 6 3 \%}$, the mean of students mastering Badminton Service hitting skills was $\mathbf{8 1 . 8 4 \%}$. The data is presented in the following diagram below this: 


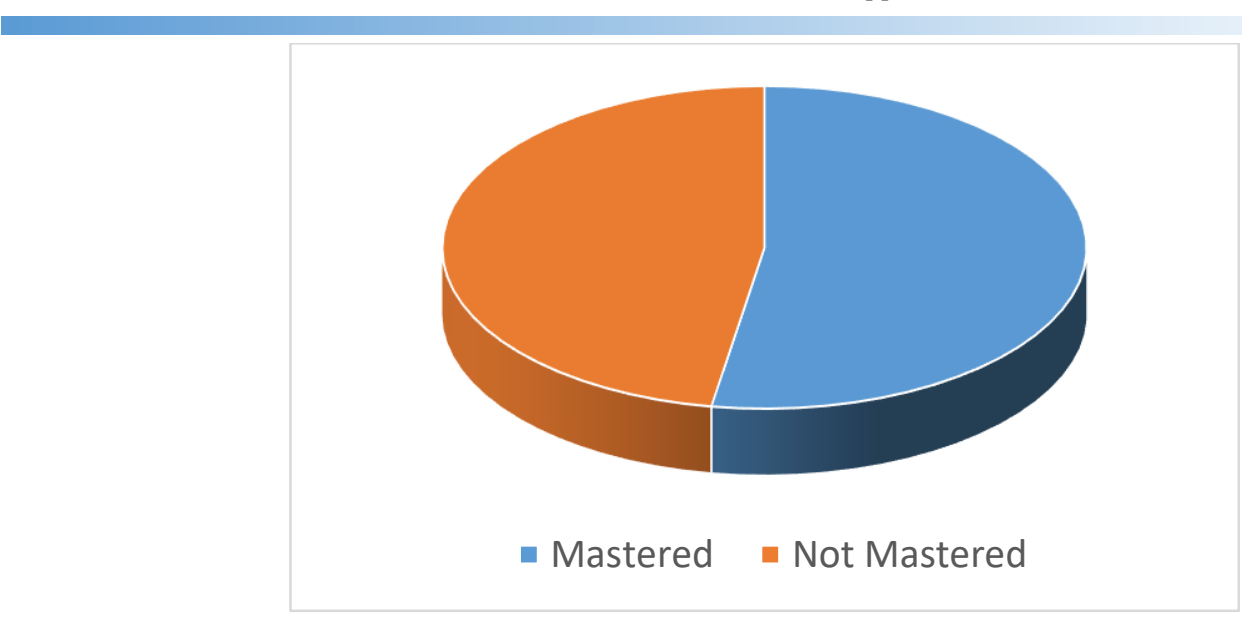

Fig. 4. Diagram of Service Mastery of Badminton with Criteria After Cycle II

In Fig 5 is the obtained data continued to observe and compare with the initial conditions. After that, it concluded that the students mastered the skill in initial condition / pre-cycle is 9 students increased to 13 students in cycle 1 , and increased to 20 students in cycle 2 . And, the mean score of mastery of Service hitting skills of Badminton from 59.74\% increased to $67.89 \%$ in cycle 1 and increased to 81.84 in cycle 2 . The data is presented in the following diagram below this:

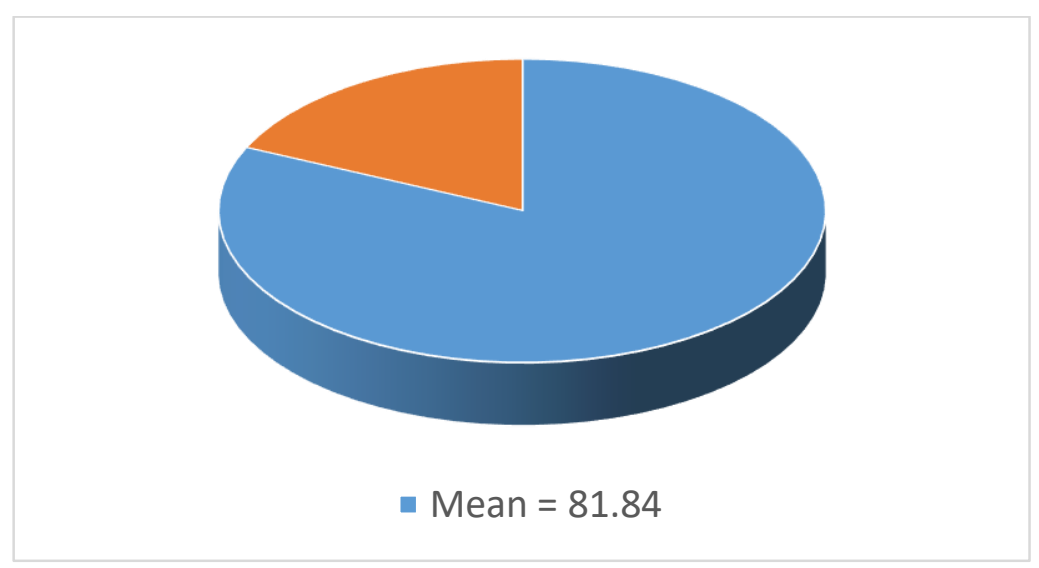

Fig. 5. Diagram of the mean class of Service Mastery of Badminton After Cycle II.

After obtaining the score after Cycle I and Cycle II, the next step is to compare the obtained data with the performance indicators which is the increasing ability to basic movement of service hitting of Badminton, marked by the increasing score and percentage of basic movement skills of Services hitting of Badminton. The indicator of success is the Minimum completeness Criteria (KKM) of 75. So, students obtained score more than 75 are completed or mastered, while students obtained score less than 75 are incomplete or not mastered. In sum, 20 students mastered the skills or $\mathbf{5 2 . 6 3 \%}$.From the data, it concluded the problem-based learning approach through games to improve service hitting skills. The obtained data were used as a reference that the approach can improve the Service hitting skills of Badminton. From the initial test, the percentage of success with the criteria of "mastered" was $\mathbf{2 3 . 6 8 \%}$.

Then, after given treatment on cycle I and cycle II, the percentage increased to $52.63 \%$. Also, the mean score on the aspect of mastery of Service hitting of Badminton, which in the initial conditions was $59.74 \%$, increased to $\mathbf{8 1 . 8 4 \%}$. The data is presented in the following tabel below this in Table 3 . 
Table 3.

Research Result on Cycle I and Cycle II

\begin{tabular}{|c|c|c|c|c|c|c|c|c|c|}
\hline Data & $\begin{array}{l}\text { n Pre- } \\
\text { Cycle }\end{array}$ & $(\%)$ & Criteria & $\begin{array}{c}\text { n Cycle } \\
\text { I }\end{array}$ & $(\%)$ & Criteria & $\begin{array}{c}\text { n Cycle } \\
\text { II }\end{array}$ & $(\%)$ & Criteria \\
\hline N 1 & 10 & $100 \%$ & Mastered & 10 & $100 \%$ & Mastered & 10 & $100 \%$ & Mastered \\
\hline $\mathrm{N} 2$ & 10 & $100 \%$ & Mastered & 10 & $100 \%$ & Mastered & 10 & $100 \%$ & Mastered \\
\hline N 3 & 3 & $30 \%$ & No & 6 & $60 \%$ & No & 6 & $60 \%$ & No \\
\hline N 4 & 5 & $50 \%$ & No & 5 & $50 \%$ & No & 7 & $70 \%$ & No \\
\hline N 5 & 10 & $100 \%$ & Mastered & 10 & $100 \%$ & Mastered & 10 & $100 \%$ & Mastered \\
\hline N 6 & 5 & $50 \%$ & No & 6 & $60 \%$ & No & 6 & $60 \%$ & No \\
\hline N 7 & 2 & $20 \%$ & No & 3 & $30 \%$ & No & 10 & $100 \%$ & Mastered \\
\hline N 8 & 5 & $50 \%$ & No & 5 & $50 \%$ & No & 7 & $70 \%$ & No \\
\hline N 9 & 3 & $30 \%$ & No & 6 & $60 \%$ & No & 10 & $100 \%$ & Mastered \\
\hline N 10 & 7 & $70 \%$ & No & 7 & $70 \%$ & No & 7 & $70 \%$ & No \\
\hline N 11 & 5 & $50 \%$ & No & 5 & $50 \%$ & No & 5 & $50 \%$ & No \\
\hline $\mathrm{N} 12$ & 8 & $80 \%$ & No & 10 & $100 \%$ & Mastered & 10 & $100 \%$ & Mastered \\
\hline N 13 & 10 & $100 \%$ & Mastered & 10 & $100 \%$ & Mastered & 10 & $100 \%$ & Mastered \\
\hline N 14 & 4 & $40 \%$ & No & 4 & $40 \%$ & No & 7 & $70 \%$ & No \\
\hline N 15 & 6 & $60 \%$ & No & 6 & $60 \%$ & No & 6 & $60 \%$ & No \\
\hline N 16 & 8 & $80 \%$ & No & 10 & $100 \%$ & Mastered & 10 & $100 \%$ & Mastered \\
\hline N 17 & 7 & $70 \%$ & No & 7 & $70 \%$ & No & 7 & $70 \%$ & No \\
\hline N 18 & 7 & $70 \%$ & No & 7 & $70 \%$ & No & 10 & $100 \%$ & Mastered \\
\hline N 19 & 6 & $60 \%$ & No & 6 & $60 \%$ & No & 10 & $100 \%$ & Mastered \\
\hline N 20 & 2 & $20 \%$ & No & 3 & $30 \%$ & No & 3 & $30 \%$ & No \\
\hline N 21 & 10 & $100 \%$ & Mastered & 10 & $100 \%$ & Mastered & 10 & $100 \%$ & Mastered \\
\hline N 22 & 7 & $70 \%$ & No & 7 & $70 \%$ & No & 7 & $70 \%$ & No \\
\hline $\mathrm{N} 23$ & 10 & $100 \%$ & Mastered & 10 & $100 \%$ & Mastered & 10 & $100 \%$ & Mastered \\
\hline N 24 & 5 & $50 \%$ & No & 5 & $50 \%$ & No & 5 & $50 \%$ & No \\
\hline $\mathrm{N} 25$ & 10 & $100 \%$ & Mastered & 10 & $100 \%$ & Mastered & 10 & $100 \%$ & Mastered \\
\hline N 26 & 2 & $20 \%$ & No & 3 & $30 \%$ & No & 7 & $70 \%$ & No \\
\hline N 27 & 4 & $40 \%$ & No & 4 & $40 \%$ & No & 4 & $40 \%$ & No \\
\hline N 28 & 6 & $60 \%$ & No & 6 & $60 \%$ & No & 10 & $100 \%$ & Mastered \\
\hline N 29 & 3 & $30 \%$ & No & 3 & $30 \%$ & No & 10 & $100 \%$ & Mastered \\
\hline N 30 & 10 & $100 \%$ & Mastered & 10 & $100 \%$ & Mastered & 10 & $100 \%$ & Mastered \\
\hline N 31 & 3 & $30 \%$ & No & 6 & $60 \%$ & No & 6 & $60 \%$ & No \\
\hline N 32 & 7 & $70 \%$ & No & 10 & $100 \%$ & Mastered & 10 & $100 \%$ & Mastered \\
\hline N 33 & 3 & $30 \%$ & No & 3 & $30 \%$ & No & 7 & $70 \%$ & No \\
\hline N 34 & 10 & $100 \%$ & Mastered & 10 & $100 \%$ & Mastered & 10 & $100 \%$ & Mastered \\
\hline N 35 & 3 & $30 \%$ & No & 3 & $30 \%$ & No & 7 & $70 \%$ & No \\
\hline N 36 & 2 & $20 \%$ & No & 6 & $60 \%$ & No & 10 & $100 \%$ & Mastered \\
\hline N 37 & 6 & $60 \%$ & No & 10 & $100 \%$ & Mastered & 10 & $100 \%$ & Mastered \\
\hline N 38 & 3 & $30 \%$ & No & 6 & $60 \%$ & No & 7 & $70 \%$ & No \\
\hline $\begin{array}{l}\text { Total } \\
\text { of score }\end{array}$ & 227 & & 9 & 258 & $68 \%$ & 13 & 311 & $82 \%$ & 20 \\
\hline Mean & 5.97 & $59.7 \%$ & $23.68 \%$ & 6.79 & $67.9 \%$ & $34.21 \%$ & 8.18 & $81.8 \%$ & $52.63 \%$ \\
\hline
\end{tabular}

\section{Discussion}

Based on the results of research that is the result, the existence of an increase in the ability of services made by students with learning models that are applied problem-based learning. The results of the study also revealed that the problem-based learning model helps students to solve problem solving because debates involving students differ from one another. The results revealed that the problem-based learning model provided an increase in the second cycle after the first cycle. Problembased prohibitions can also be applied to other learning to solve problems encountered during the learning and teaching process, this study also discusses if this learning model is effective in improving solving problems carried out in learning so that students can think to overcome disabilities in learning that do not exceed the KKM target in need. Although the problem-based learning model of learning has an increase in this study it still has shortcomings namely, research is limited to only third-grade students, this study also only took one location where the study was conducted. Problem-based learning can be used as a reference or carried out for further research on the problems that can be done on the learning model, but the need for additional discussion for further research, as can be added to research conducted through research. 
The results of this research are by the theory nor preliminary study of problem-based learning can be one of the learning models in solving problems faced by students. In line with this opinion, research by explains that long service skills in badminton games can be improved using the method of probed learning. Furthermore, he explained that using this model students were able to identify weaknesses or problems that were encountered so that the results of the services that were performed were not as they were supposed to be [1]. Yane also explained the results of his research, namely, there was an increase in badminton long service skills which was quite good, namely in cycle I with an average value of 60.20 or in a percentage of $35.71 \%$ while the average value in cycle II was 74.15 or as a percentage of $78.57 \%$ [12] revealed that there is an influence of problem-based learning models with experimental methods and discussions on learning outcomes, Scientific Attitudes affect student learning outcomes, there is no interaction between problem-based learning models with experimental methods and discussions with scientific attitudes towards learning outcomes This study shows that the average value of the posttest I experimental class is 76.50 and the experimental class II at 79.83 with the average value of the scientific attitude towards the experimental class I is 52.42 and 50.70 of the experimental class. Furthermore, he explained that through this learning model students are required to be able to think critically through the problems they face and how to solve the problems themselves. This learning model also results in the activeness of students in learning to minimize the mistakes made.

Revealed that students who were given the knowledge of the learning model of problem-based learning showed productive and positive results on the ability of students to understand and study the learning of Physical Education [13]. Furthermore, he explained the results of his research, namely, the results of the T-test coefficient was 5,973 and increased by 5\%. There is a big difference in the average value of the experiment in the experimental group and the control group and obtained the average value of the experimental group is 82.944 higher than the control group 69.583. The application of learning model based on problem-based learning is expected to be applied by other teachers in conveying learning, in implementing this learning model the teacher is expected to be able to provide material and actively involve students in learning so that the learning given by the teacher can be applied in daily life by students. Explained that the PBL learning model can optimize the potential of students, whether physical or mental potential, so they can think critically [14]. Based on the conclusions of this study, it advises geography students to use PBL as an alternative when they teach increasing students to get results. For further researchers who will use the PBL model, they must give more time to allocate some repetition in the implementation of this model. Moreover, the fumbling must be based on the ability of the heterogeneity of students.

Revealed that the problem-based learning model which is intended to have a good impact is, there is an increase in student learning outcomes using the PBL model, the creative thinking ability of students using the PBL model is better than using conventional models, there are supporting factors and inhibitors in increasing students' creative thinking abilities [15]. The application of problem-based learning models has a good influence on learning outcomes and skills in science learning subjects of class XI students of SMA Negeri 1 Jepara on salt hydrolysis material. He further revealed that the results of the calculations that were obtained through the calculation of the coefficient of determination revealed that the application of the problem-based learning model contributed $35.00 \%$ to the learning outcomes and $19.36 \%$ to the science process skills. The relationship between science process skills and learning outcomes in learning problem based learning models obtained by $31.82 \%$. Revealed that in the face of data collected and evaluations carried out in research, it was determined that the active problem-based implementation of the learning model had positively influenced students' academic achievement and attitudes towards science courses [16]. It was also found that the active problembased application of the learning model positively affects students' conceptual development and maintains misconceptions at the lowest level. Revealed that PBL is 'a fun way to learn', 'it gives freedom to interact with peers', 'it helps improve concentration, critical thinking, and practical skills' [17]. On the other hand, it was suggested that it would be beneficial for the less confident students if the lecturer gave demonstration procedures in starting from practical classes. Discussion: The findings show exceptional student support for PBL as an alternative method of teaching and learning in Indonesian sports science. With PBL the lecturer facilitates rather than dictating the learning process that is beneficial for students' journey towards independent learning.

Revealed that the increase in scientific literacy achievement of students learning integrated science through guided discovery and problem-based learning models did not differ significantly [18]. 
Integrated science learning through guided models can improve student literacy achievement with a gain of 0.37 (medium category) while using problem-based learning models can increase science literacy with a gain of 0.41 (medium category). It can be concluded that both the guided discovery model and problem-based learning can improve students' scientific literacy. Revealed that the PBL curriculum yielded significantly more exam performance than that of the traditional teaching curriculum, both for choice and viva questions [19]. No differences in learning styles or attitudes towards psychiatry were found between the curriculum. Students were significantly more successful on the exam if they had received the PBL curriculum, were women and used strategic learning. Revealed that the statement that problems involving Tired in educational practice usually originated from the poor implementation of PBL [20]. In many cases, the PBL access paths applied are not consistent with current learning insights. Also, it is argued that research on PBL should contribute to a better understanding of why and how its concepts are constructive, independent, collaborative and work on textual learning or do not work and under what circumstances. Example studies are given to illustrate this problem. Revealed that one of the advantages of the problem-based learning approach is that this approach is oriented towards students' ability to process information [21]. This information processing refers to the way students interact with their environment, see problems, develop concepts, and solve those problems. Thus the ability to think critically can develop because in this study the critical thinking skills observed include the ability to identify problems, analyze problems, solve problems, and draw conclusions precisely.

Revealed their research that is, investigating the effects of Problem Based Learning (PBL) on preservice teacher performance on conceptual and quantitative problems regarding gas concepts. Analysis of the results of the study showed that students at the University of Muhammadiyah Malang experimental group had better performance on conceptual problems while there were no differences in student performance from quantitative problems [22]. The results of the study are discussed in terms of the effect of PBL on students' conceptual learning. PBL in this study shows positive results on teacher performance regarding the delivery in learning the concept of gas, said that learning using problem-based learning can improve students' cognitive values in learning, the results of this study also exceed drinking criteria so that mathematics and physics learning can pass through KKM [23]. Furthermore, explaining the results of his research that is, problem-based learning able to improve the criteria for developing problem-based learning teaching materials is 5 level categories when $43.33 \%$ of respondents rate category 5 levels and others provide 4 level categories.

Revealed that the research conducted by him to find out the application of problem-based learning models for 1) differences in concept understanding and ability to solve mathematical problems between students who were facilitated with problem-based learning models and who were facilitated with conventional learning models; 2) differences in understanding concepts and the ability to solve mathematical problems between students who are facilitated by authentic assessment and those who are facilitated by conventional assessment and 3) the effect of the interaction between learning models and assessment models on understanding concepts and the ability to solve mathematical problems [24]. The results obtained are, the application of learning through the problem-based learning model shows significantly that: (1) there is a difference in the understanding of concepts in mathematical problem-solving abilities between students facilitated with problem-based learning models and those who are facilitated with conventional models; (2) there are differences in the concepts of understanding and problem-solving ability between students who are facilitated with authentic assessments, and those who are facilitated with conventional assessments; and (3) there is an interaction effect between learning and assessment models on conceptual understanding and the ability to solve mathematical problems explained that the application of the problem-based learning model had a significant effect on the learning history of fifth-grade students at SDN 46 Banda Aceh [25]. Problem-based learning can be a solution to solve the problem of learning history in appreciating historical heritage material for fifth-grade students at SD Negeri 46 Banda Aceh. 


\section{Conclusion}

Based on the results of research that has been carried out in two cycles, it can be concluded that there is an increase in students' badminton service capability after the problem-based learning model is applied. Problem-based learning is considered the right learning model to solve the problem because in this model students are required to be able to identify the perceived problems in doing services in badminton that are different in each individual. Despite the improvement, this study has limitations in the sample and limited research sites, the results of this study are expected to be a reference for further research but also pay attention to other factors that affect the improvement in service results in badminton that are not identified in this study.

\section{Acknowledgment}

Thank you as the author of this journal to all those involved in making this manuscript and thank you to the journal IJELE for allowing me to publish this journal.

\section{References}

[1] S. Yane, "Peningkatan Servis Panjang Bulutangkis Melalui Model Problem Based Learning," J. Pendidik. Olahraga, vol. 5, no. 2, pp. 165-174, 2016, doi: 10.31571/jpo.v5i2.384.

[2] S. Ardyanto, "Peningkatan Teknik Servis Pendek Pada Bulutangkis Melalui Media Audio Visual," J. Ilm. Penjas, vol. 4, no. 3, pp. 21-32, 2018, available at: Google Scholar.

[3] S. K. Purnama, Kepelatihan bulutangkis modern. Surakarta: Yuma Pustaka, 2010, available at: Google Scholar.

[4] A. Setiawan and G. Dermawan, "Penerapan Media Audio Visualterhadap Peningkatan Teknik Servis Pendek," J. Pendidik. Olahraga dan Kesehat., vol. 2, no. 2, pp. 341-344, 2014, available at: Google Scholar.

[5] W. Sanjaya, Strategi pembelajaran berorientasi standar proses pendidikan. Jakarta: Prenada Media, 2008, available at: Google Scholar.

[6] B. Astuti, D. S. Purnama, and E. P. Laksana, "Stress reduction in thesis completion through peer tutoring method," Psychol. Eval. Technol. Educ. Res., vol. 1, no. 2, pp. 73-81, Aug. 2019, doi: 10.33292/petier.v1i2.23.

[7] M. N. Hudha et al., "Scientific performance e-rubric-assisted problem-based learning for improving learning effectiveness," 2018, doi: 10.1088/1742-6596/1318/1/012004.

[8] M. T. Amir, Inovasi pendidikan melalui problem based learning: Bagaimana pendidik memberdayakan pemelajar di era pengetahuan. Jakarta: Prenada Media Group, 2010, available at: Google Scholar.

[9] T. Trianto, Mendesain model pembelajaran inovatif-progresif: konsep, landasan, dan imlementasinya pada kurikulum tingkat satuan pendidikan (KTSP). Jakarta: Kencana, 2010, available at: Google Scholar.

[10] Y. N. Nafiah and W. Suyanto, "Penerapan model problem-based learning untuk meningkatkan keterampilan berpikir kritis dan hasil belajar siswa," J. Pendidik. Vokasi, vol. 4, no. 1, pp. 125-143, 2014, doi: 10.21831 /jpv.v4i1.2540.

[11] M. I. Supiandi and H. Julung, "Pengaruh Model Problem Based Learning (PBL) terhadap Kemampuan Memecahkan Masalah dan Hasil Belajar Kognitif Siswa Biologi SMA,” JPS (Jurnal Pendidik. Sains), vol. 4, no. 2, pp. 60-64, 2016, doi: 10.17977/jps.v4i2.8183.

[12] E. Siswantoro, "Problem Based Learning Untuk Meningkatkan Kemampuan Pemecahan Masalah Siswa Kelas VI SD Negeri Sanawetan 2 Kota Blitar," J. Edukasi, vol. 5, no. 1, p. 15, 2018, doi: 10.19184/jukasi.v5i1.8009.

[13] M. K. Azmi, S. Rahayu, and H. Hikmawati, "Pengaruh Model Problem Based Learning dengan Metode Eksperimen dan Diskusi Terhadap Hasil Belajar Fisika Ditinjau dari Sikap Ilmiah Siswa Kelas X MIPA SMA N 1 Mataram," J. Pendidik. Fis. dan Teknol., vol. 2, no. 2, p. 86, 2017, doi: 10.29303/jpft.v2i2.294.

[14] N. S. Masholekhatin, B. Handoyo, and Sumarmi, "Pengaruh Model Pembelajaran Problem Base Learning ( PBL ) Terhadap Hasil Belajar Geografi," Lap. Penelit., 2012, available at: Google Scholar.

[15] R. Abdurrozak and A. K. Jayadinata, "Pengaruh Model Problem Based Learning Terhadap Kemampuan Berpikir Kreatif Siswa,” vol. 1, no. 1, pp. 871-880, 2016, doi: 10.23819/pi.v1i1.3580. 
[16] M. Musdiani, “The Influence of Problem-Based Learning Model on Learning IPS,” J. Ilm. Peuradeun, vol. 6, no. 2, p. 267, 2018, doi: 10.26811/peuradeun.v6i2.220.

[17] O. A. and R. Ö. Tandoğan, "In vitro biocompatibility of electrospun poly(3-hydroxybutyrate) and poly(3hydroxybutyrate-co-3-hydroxyvalerate) fiber mats," Int. J. Biol. Macromol., vol. 40, no. 3, pp. 217-223, 2007, doi: 10.1016/j.ijbiomac.2006.07.006.

[18] M. Konstantaki, “Applying Problem based learning in the Sports Science Curriculum,” Athens J. Sport., vol. 2, no. 1, pp. 7-16, 2015, available at: Google Scholar.

[19] D. Ardianto and B. Rubini, “Comparison of students' scientific literacy in integrated science learning through model of guided discovery and problem based learning," J. Pendidik. IPA Indones., vol. 5, no. 1, pp. 31-37, 2016, doi: 10.15294/jpii.v5i1.5786.

[20] L. M. N. \& G. L. Monica McParland, "The effectiveness of problem-based learning compared to traditional teaching in undergraduate psychiatry," pp. 859-867, 2004, doi: 10.1111/j.13652929.2004.01818.x.

[21] D. H. J. M. Dolmans, W. De Grave, I. H. A. P. Wolfhagen, and C. P. M. Van Der Vleuten, "Problembased learning: Future challenges for educational practice and research," Med. Educ., vol. 39, no. 7, pp. 732-741, 2005, doi: 10.1111/j.1365-2929.2005.02205.x.

[22] K. F. Zamzam, "Pendekatan Problem Based Learning untuk Mengembangkan Kemampuan Berpikir Kritis Mahasiswa,” J. Pedagog., vol. 5, no. 2, pp. 17-27, 2016, doi: 10.21070/pedagogia.v5i2.261.

[23] I. Bilgin, E. Şenocak, and M. Sözbilir, "The effects of problem-based learning instruction on university students' performance of conceptual and quantitative problems in gas concepts," Eurasia J. Math. Sci. Technol. Educ., vol. 5, no. 2, pp. 153-164, 2009, available at: eric.ed.gov.

[24] P. Pujayanto, S. Supurwoko, Y. Radiyono, and D. W. Adi, "Development of problem-based learning material for physics mathematics and its implementation," Int. J. Sci. Appl. Sci. Conf. Ser., vol. 1, no. 1, p. 16, 2017, doi: 10.20961/ijsascs.v1i1.5104.

[25] I. K. Darma, "Problem-based learning and authentic assessment on conceptual understanding and ability to solve mathematical problems," Int. Res. J. Eng. IT Sci. Res., vol. 4, no. 4, pp. 7-16, 2018, doi: 10.21744/irjeis.v4n4.254. 